\title{
The EfFect of InPut DeVice Profile on COLOUR IMAGE REPRODUCTION
}

\author{
Strgar Kurecic, M.; Agic, D. \& MANDiC, L.
}

Abstract: This research deals with a problem of colour accurate image reproduction. In everyday practice many prepress and graphic production experts have a problem with colour image reproduction and the need for excessive colour editing of captured images, witch have serious impact on workflow efficiency. Quality of the reproduction and efficiency of the reproduction process can significantly increase by implementing colour management system at the beginning of the reproduction chain. In this research, the conventional (analog) and digital workflow with implemented colour management will be compared, with main focus on the effect of input profiles on colour image reproduction. The objective of this research is to propose a new solution to the problem of colour accurate reproduction. The solution involves using precisely characterized input device (analog and digital camera, in the case of this experiment). For that purpose, the object specific colour test target was developed, used and tested in this research.

Key words: colour image reproduction, colour management, custom colour target, device profile, device characterization
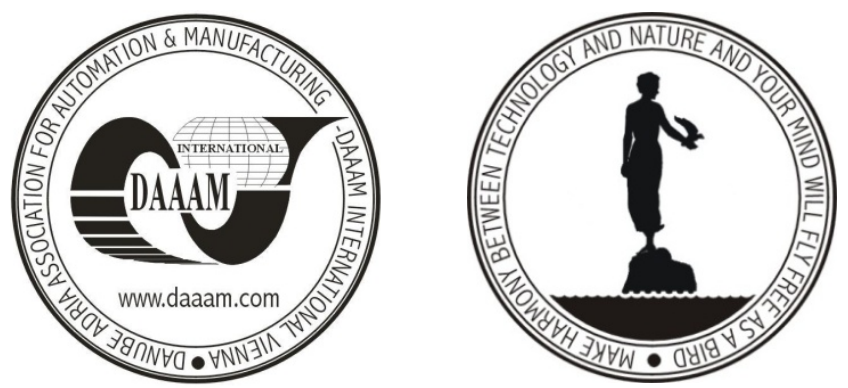

Authors' data: Ph.D. Strgar Kurecic, M[aja]; Dr. Agic, D[arko]; Dr. Mandic, L[idija], Faculty of Graphic Arts University of Zagreb, Getaldiceva 2, 10000, Zagreb, HR, mstrgar@grf.hr, darkoagic@grf.hr, lidijamandic@grf.hr

This Publication has to be referred as: Strgar Kurecic, M[aja]; Agic, D[arko] \& Mandic, L[idija] (2008). The Effect of Input Device Profile on Colour Image Reproduction, Chapter 70 in DAAAM International Scientific Book 2008, pp.863872, B. Katalinic (Ed.), Published by DAAAM International, ISBN 978-3-90150966-7, ISSN 1726-9687, Vienna, Austria

DOI: $10.2507 /$ daaam.scibook.2008.70 